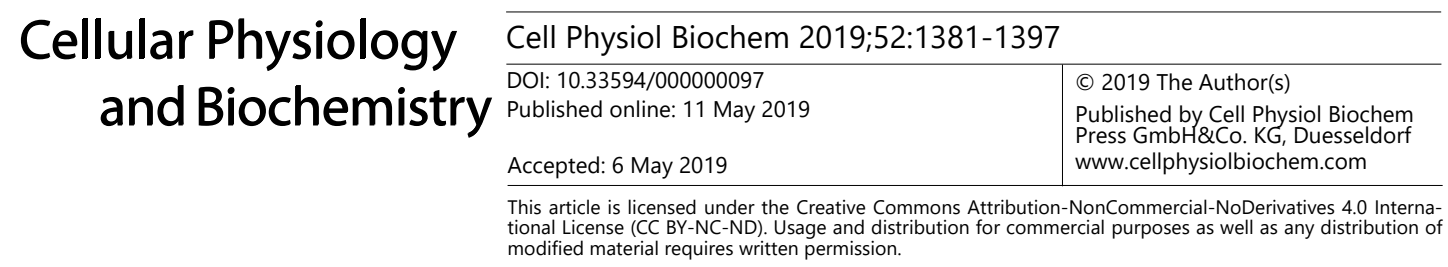

Original Paper

\title{
Ouabain Modulates the Adherens Junction in Renal Epithelial Cells
}

\author{
Aida Castillo ${ }^{a}$ Carlos Ortuño-Pineda ${ }^{b}$ Catalina Flores-Maldonado Isabel Larre ${ }^{c}$ \\ Jacqueline Martínez Rendón ${ }^{a} \quad$ Lorena Hinojosa ${ }^{a} \quad$ Arturo Ponce $^{a} \quad$ Alejandro Ogazón ${ }^{a}$ \\ Mauricio Serrano ${ }^{a}$ Jesús Valdes ${ }^{d}$ Rubén G. Contreras ${ }^{a} \quad$ Marcelino Cereijido $^{a}$ \\ aDepartment of Physiology, Biophysics and Neurosciences, Cinvestav, Mexico City, Mexico, bLaboratory \\ of Nucleic Acids and Proteins, Faculty of Chemical and Biological Sciences, Autonomous University of \\ Guerrero, Chilpancingo, Mexico, 'Marshall Institute for Interdisciplinary Research and Department of \\ Clinical and Translational Sciences, Joan C. Edwards School of Medicine, Marshall University, \\ Huntington, WV, USA, dDepartment of Biochemistry, Cinvestav, Mexico City, Mexico
}

\section{Key Words}

Ouabain • Adherens Junction • Epithelial Cell $\bullet \mathrm{Na}^{+}, \mathrm{K}^{+}$-ATPase $\bullet \beta$-catenin $\bullet$ E-cadherin

\begin{abstract}
Background/Aims: Ouabain, a well-known plant-derived toxin, is also a hormone found in mammals at nanomolar levels that binds to a site located in the $\alpha$-subunit of $\mathrm{Na}^{+}, \mathrm{K}^{+}$-ATPase. Our main goal was to understand the physiological roles of ouabain. Previously, we found that ouabain increases the degree of tight junction sealing, GAP junction-mediated communication and ciliogenesis. Considering our previous results, we investigated the effect of ouabain on adherens junctions. Methods: We used immunofluorescence and immunoblot methods to measure the effect of $10 \mathrm{nM}$ ouabain on the cellular and nuclear content of E-cadherin, $\beta$-catenin and $\gamma$-catenin in cultured monolayers of Marin Darby canine renal cells (MDCK). We also studied the effect of ouabain on adherens junction biogenesis through sequential $\mathrm{Ca}^{2+}$ removal and replenishment. Then, we investigated whether c-Src and ERK1/2 kinases are involved in these responses. Results: Ouabain enhanced the cellular content of the adherens junction proteins E-cadherin, $\beta$-catenin and $\gamma$-catenin and displaced $\beta$-catenin and $\gamma$-catenin from the plasma membrane into the nucleus. Ouabain also increased the expression levels of $\mathrm{E}$-cadherin and $\beta$-catenin in the plasma membrane after $\mathrm{Ca}^{2+}$ replenishment. These effects on adherens junctions were sensitive to PP2 and PD98059, suggesting that they depend on c-Src and ERK $1 / 2$ signaling. The translocation of $\beta$-catenin and $\gamma$-catenin into the nucleus was specific because ouabain did not change the localization of the tight junction proteins ZO- 1 and ZO-2. Moreover, in ouabain-resistant MDCK cells, which express a $\mathrm{Na}^{+}, \mathrm{K}^{+}$-ATPase $\alpha 1$-subunit with low affinity for ouabain, this hormone was unable to regulate adherens junctions, indicating
\end{abstract}




\section{Cellular Physiology Cell Physiol Biochem 2019;52:1381-1397 \\ \begin{tabular}{ll|l} 
and Biochemistry $10.33594 / 000000097$ & (c) 2019 The Author(s). Published by \\
Cublished online: 11 May 2019 & Cell Physiol Biochem Press GmbH\&Co. KG
\end{tabular}

that the ouabain receptor that regulates adherens junctions is $\mathrm{Na}^{+}, \mathrm{K}^{+}$-ATPase. Conclusion: Ouabain $(10 \mathrm{nM})$ upregulated adherens junctions. This novel result supports the proposition that one of the physiological roles of this hormone is the modulation of cell contacts.

(C) 2019 The Author(s). Published by Cell Physiol Biochem Press GmbH\&Co. KG

\section{Introduction}

The very high affinity of ouabain for the $\alpha$-subunit of $\mathrm{Na}^{+}, \mathrm{K}^{+}$-ATPase has led to speculation that there may be an endogenous analog of this substance. This hypothesis has been verified because ouabain has been found in human plasma [1]. Experimental studies using labeled precursors ( ${ }^{3} \mathrm{H}$-cholesterol) and bioinformatics and genomic techniques have shown that ${ }^{3} \mathrm{H}$-ouabain is synthesized in cells obtained from the hypothalamus and suprarenal glands [2-5]. Subsequent studies demonstrated that under physiological conditions in dogs and humans, there is a concentration of $0.05-3.70 \mathrm{nM}$ ouabain in plasma [6, 7]. In physical exercise, renal failure, some forms of arterial hypertension and in the regulation of natriuresis, the plasma level of endogenous ouabain increases markedly, and in eclampsia, it may reach up to $700 \mathrm{nM}[6,8-10]$. Ouabain is considered a hormone $[11,12]$ that regulates blood pressure and $\mathrm{Na}^{+}$homeostasis $[8,10,13]$. In cultured cells, ouabain induces contractility, proliferation and hypertrophy [14-16]; it also protects epithelial and muscle cells from apoptosis induced by serum deprivation $[17,18]$; and it protects renal epithelial cells from apoptosis induced by malnutrition in developing mice [19, 20] and proteinuric kidney disease [21]. In addition to functioning as an ion transporter, $\mathrm{Na}^{+}, \mathrm{K}^{+}$-ATPase is a receptor whose $\alpha$-subunit binds cardiotonic steroids and transduces this information to several intracellular signaling pathways, such as c-Src, ERK1/2 and AMPK [18, 22, 23].

$\mathrm{Na}^{+}, \mathrm{K}^{+}$-ATPase also plays an important role as an adhesion protein; in this respect, the $\beta$-subunit is a cell-cell adhesion protein in glial [24] and epithelial [25] cells. The intercellular adhesion conferred by the $\beta$-subunit in epithelial cells requires homotypic interactions between the extracellular domains of neighboring cells [26] and is necessary to maintain enzyme polarization in the lateral domain [27-29], where it must be localized to promote transepithelial transport [30,31]. Glycosylation of the $\beta$-subunit is necessary for the association of $\mathrm{Na}^{+}, \mathrm{K}^{+}$-ATPase with adherens junctions [32], and the homotypic interaction depends on a 10 amino acid acidic extracellular region of the $\beta$-subunit [33]. The activity of $\mathrm{Na}^{+}, \mathrm{K}^{+}$-ATPase is necessary for tight junction formation [34], and dysadherin, a regulatory $\gamma$-subunit of $\mathrm{Na}^{+}, \mathrm{K}^{+}$-ATPase that is overexpressed in cancer cells, downregulates E-cadherin, impairs cell-cell adhesion and promotes metastasis [35, 36].

Ouabain has opposing effects on epithelial cell adhesion depending on the concentration. At high concentrations ( $300 \mathrm{nM}$ or greater), ouabain increases the endocytosis and degradation of proteins of the tight junction, opens tight junctions, detaches MDCK cells from neighboring cells and substrates and induces cell death [37, 38]; however, at $10 \mathrm{nM}$, a typical concentration in physiological and pathological conditions, ouabain increases the expression of claudins, the degree of tight junction sealing [39] and cell-cell communication through GAP junctions [40,41] and accelerates ciliogenesis [42]. These data suggest that ouabain is a hormone that regulates cell adhesion [43]. Pursuing the systematic studies on the effect of $10 \mathrm{nM}$ ouabain on several types of cell contacts, in this study, we investigated its effect on adherens junctions.

Adherens junctions appear as bands encircling cells (zonula adherens) or as locations of attachment (adhesion plaques) between cells. In epithelial cells, adherens junctions are located directly below tight junctions $[44,45]$. Adherens junctions are formed by cadherins, which are $\mathrm{Ca}^{2+}$-dependent cell-cell adhesion proteins. The cytosolic portion of cadherins binds intracellular proteins called $\alpha-, \beta-, \gamma$ - and p120 catenins. $\alpha$-catenin links the protein complex to the actin cytoskeleton $[46,47]$. $\beta$-catenin is involved in adhesion in conjunction with E-cadherin at the cell membrane, but it also participates as a key member of the WNT signaling pathway that is translocated into the nucleus to regulate transcription [48]. Furthermore, we have shown that $100 \mathrm{nM}$ ouabain induces the translocation of $\beta$-catenin 


\section{Cellular Physiology Cell Physiol Biochem 2019;52:1381-1397

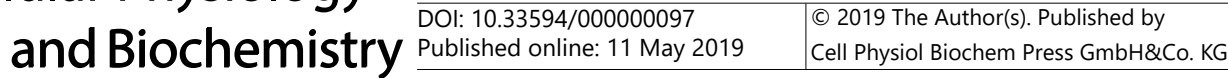 \\ Castillo et al.: Ouabain Influences Adherens Junctions}

into the nucleus $[31,49]$. Because of the involvement of adherens junctions in a multitude of physiological and pathological phenomena, such as cancer and metastasis, the findings regarding its sensitivity to ouabain described in this study might contribute to improving the understanding of the role of ouabain as a hormone that regulates cell adhesion.

Following our previous investigation of the effect of low-concentration ouabain on cell contacts, this study focuses on whether $10 \mathrm{nM}$ ouabain can modulate zonula adherens. For this purpose, we evaluated the expression of E-cadherin and $\beta$ - and $\gamma$-catenin proteins by immunofluorescence and Western blotting. We examined the biogenesis of adherens junctions through rapid calcium removal and restoration methods that allowed us to evaluate the polarized delivery of proteins to cell borders and investigated whether c-Src and ERK1/2 kinases are involved in these responses. The novel finding of this study is that $10 \mathrm{nM}$ ouabain modulates adherens junctions.

\section{Materials and Methods}

\section{Antibodies and Chemicals}

Monoclonal antibodies against uvomorulin/E-cadherin, clone DECMA-1 (Cat. No. U 3254) and ouabain (0-3125) were obtained from Sigma-Aldrich, St. Louis MO, USA. Antibodies against $\beta$-catenin (Cat. No. 138400), ZO-2 (Cat. No. 71-1400), HRP-anti-mouse (Cat. No. 61-6620), HRP-anti-rabbit (Cat. No. 62-6120), FITC-anti-rabbit (Cat. No. F2765), TRITC-anti-mouse (Cat. No. 62-6514), FITC-goat anti-rat (Cat. No. A18872), and goat anti-rat IgG (H+L) HRP conjugate (Cat. No. 62-9520) were obtained from Thermo Fisher Scientific, Inc., Waltham, MA, USA. The antibodies against Z0-1 (Cat. No. ab61357) and $\gamma$-catenin (clone 15F11, Cat. No. ab12083) were obtained from abcam, Cambridge, MA, USA. PD98059 (PD, 2'-Amino-3'methoxyflavone), an inhibitor of the extracellular regulated kinase 1/2 (Cat. No. 51300) and PP2 (4-Amino5-(4-chlorophenyl)-7-(t-butyl) pyrazolo [3, 4-d] pyrimidine), an inhibitor of the proto-oncogene protein tyrosine kinase c-Src (Cat. No. 529573) were obtained from Calbiochem-Novabiochem, San Diego, CA, USA. The anti $\alpha$-actin antibody was a kind gift from Dr. José Manuel Hernández (Department of Cell Biology, Cinvestav) [50].

\section{Cell Culture}

Canine renal MDCK-II cells (American Type Culture Collection, CCL-34, Manassas, VA, USA) [51] and ouabain-resistant MDCK cells (R-MDCK), a generous gift from Daniel Louvard, Pasteur Institute [52, 53], were grown at $36.5^{\circ} \mathrm{C}$ in a $5 \% \mathrm{CO}_{2}$ and $95 \%$ humidified atmosphere in Dulbecco's modified Eagle's medium (DMEM; Cat. No. 121000-46, Thermo Fisher), supplemented with 10, $000 \mathrm{U} / \mu \mathrm{g} / \mathrm{ml}$ penicillin-streptomycin (In vitro, Acayucan, México) and 10\% fetal bovine serum (FBS, Cat. No. 160004-04, GIBCO, Thermo Fisher). This medium will be subsequently referred to as CDMEM. Cells were harvested with trypsin-EDTA (In vitro), suspended at a concentration of $2.5 \times 10^{5}$ cells per $\mathrm{ml}$, and $1 \mathrm{ml}$ of the suspension was plated in each well of a 24-well plate (Costar 3524, Corning, New York, NY, USA), which may have contained a glass coverslip for immunofluorescence experiments. Cells were cultured in CDMEM for $24 \mathrm{~h}$, washed with PBS and incubated in DMEM supplemented with 1\% FBS in DMEM for an additional $24 \mathrm{~h}$, then treated either with or without $10 \mathrm{nM}$ ouabain for $8 \mathrm{~h}$. The cell monolayers were exposed to PP2 and PD for $1 \mathrm{~h}$ before starting the challenge with $10 \mathrm{nM}$ ouabain. In R-MDCK cells, cysteine 113 of $\mathrm{Na}^{+}, \mathrm{K}^{+}$-ATPase is replaced by a tyrosine, rendering an ouabain-resistant enzyme with an inhibition constant 1000 -fold greater than the that of the wild-type because ouabain associates more slowly to and dissociates more rapidly from the enzyme [52, 53]. R-MDCK cells express $1.5 \times 10^{6} \mathrm{Na}^{+}, \mathrm{K}^{+}$-ATPases per cell [52] and $1.0 \times 10^{6} \mathrm{Na}^{+}, \mathrm{K}^{+}$-ATPases per wild-type cell [54].

\section{Nuclear extracts}

The cell monolayer was incubated for $5 \mathrm{~min}$ in ice-cold detachment buffer (40 mM Tris-HCl, pH 7.5, $1 \mathrm{mM}$ EDTA and $150 \mathrm{mM} \mathrm{NaCl}$ ), then the cells were detached from the surface with a scraper, and the suspension was centrifuged for $10 \mathrm{~min}$ at $300 \mathrm{xg}$ and $4^{\circ} \mathrm{C}$. The precipitate was resuspended in $5 \mathrm{ml}$ of buffer A (10 mM HEPES-KOH, pH 7.9, $1.5 \mathrm{MgCl}_{2}$ and $10 \mathrm{mM} \mathrm{KCl}$ ) supplemented with $1 \mathrm{mM}$ DTT, incubated for 10 min on ice, centrifuged at $4500 \mathrm{xg}$ and $4{ }^{\circ} \mathrm{C}$ and resuspended again in 2 volumes of buffer A containing 5 $\mu \mathrm{l}$ of a protease inhibitor cocktail (Complete ${ }^{\mathrm{TM}} 469311600$; Sigma-Aldrich). Cells in the suspension were 


\section{Cellular Physiology Cell Physiol Biochem 2019;52:1381-1397 \\ \begin{tabular}{ll|l} 
DOl: 10.33594/000000097 & $\begin{array}{l}\text { O 2019 The Author(s). Published by } \\
\text { Cell Physiol Biochem Press GmbH\&Co. }\end{array}$
\end{tabular} \\ Castillo et al.: Ouabain Influences Adherens Junctions}

lysed with 20 strokes in a glass homogenizer (Thermo Fisher, Cat. No. 10269751), and the suspension was then centrifuged at $14000 \mathrm{xg}$ for $20 \mathrm{~min}$ at $4{ }^{\circ} \mathrm{C}$. The precipitate was washed once with buffer C $(20 \mathrm{mM}$ HEPES-KOH, pH 7.9, $0.42 \mathrm{mM} \mathrm{NaCl}, 1.5 \mathrm{mM} \mathrm{MgCl}, 0.2 \mathrm{mM}$ EDTA and $25 \%$ glycerol) supplemented with 1 $\mathrm{mM}$ DTT and then resuspended in one volume of buffer $\mathrm{C}$ with protease inhibitors as indicated above. The suspension was homogenized with 20 strokes in a glass homogenizer and agitated with a small magnetic stir bar for $30 \mathrm{~min}$ at $4{ }^{\circ} \mathrm{C}$. The final suspension was centrifuged for $30 \mathrm{~min}$ at $14000 \mathrm{x} \mathrm{g}$. The supernatant was dialyzed against 50 volumes of buffer D (10 mM HEPES-KOH, pH 1.9, $100 \mathrm{mM} \mathrm{KCl}, 0.2 \mathrm{mM}$ EDTA and $20 \%$ glycerol) for $5 \mathrm{~h}$ at $4{ }^{\circ} \mathrm{C}$. Then, the buffer was changed, and the suspension was dialyzed overnight. The suspension was then recovered and centrifuged for $20 \mathrm{~min}$ at $14000 \mathrm{xg}$ at $4{ }^{\circ} \mathrm{C}$. The supernatant was recovered, aliquoted and stored at $-70^{\circ} \mathrm{C}$. Protein concentrations were quantified by the Bradford method. The purity of the nuclear extract was evaluated by PAGE and immunoblotting with antibodies against lamin B1 (Cat. No. 16048, abcam) and $\beta$-catenin.

\section{Immunofluorescence}

Cell monolayers on coverslips were washed three times with ice-cold PBS with $\mathrm{Ca}^{2+}$, fixed and permeabilized with methanol for $8 \mathrm{~min}$ at $-20^{\circ} \mathrm{C}$, washed three times with PBS, blocked for $1 \mathrm{~h}$ with $0.5 \%$ $\mathrm{BSA}$, and incubated overnight at $4{ }^{\circ} \mathrm{C}$ with a specific primary antibody, followed by three washes with PBS, and incubated with a secondary antibody against the primary antibody. The cell monolayers were then rinsed six times with PBS, incubated with a FITC- or TRITC-labeled secondary antibody according to the animal species used ( $1 \mathrm{~h}$ at room temperature), and rinsed as indicated before. Cell nuclei were stained in blue with DAPI (10236276001 ROCHE, Sigma-Aldrich, $5 \mu \mathrm{g} \cdot \mathrm{ml}^{-1}$ in PBS, $20 \mathrm{~min}$ ), then the coverslips were mounted using Vectashield mounting medium (Cat. No H-1000, Vector Laboratories) and examined by confocal microscopy (SP8, equipped with a Plan-NeoFluar 63x NA 1.4 objective, Leica Microsystems, Wetzlar, Ger). The acquired images were processed with FIJI [55] ImageJ (National Institutes of Health) and figures were constructed using GIMP (GNU image manipulation program). To measure the length of the E-cadherin linear signal at the cell border, we used a method previously described by Jouret et al. [56]. Briefly, cells were stained with antibodies against E-cadherin and DAPI to detect nuclei. We acquired confocal stacks composed of 40 to 60 images and obtained the maximum intensity projection from each image. Then, we drew free-hand lines superimposed on the linear E-cadherin signals at the cell border and measured their lengths using FIJI. Then, we added the length values of the signals and reported the average of the total length per nucleus from 22-53 cells obtained from 2 to 10 images in 3 independent experiments. To measure the amount of $\beta$-catenin in the nucleus, we used FIJI software, identified the nucleus by its DAPI signal, encircled it with the oval tool in the software and measured the average intensity of the fluorescence signal of $\beta$-catenin in images obtained from four independent experiments.

\section{Rapid calcium removal and restoration}

Mature confluent cell monolayers, grown on glass coverslips, were washed twice with DMEM. Then, they were incubated for $2 \mathrm{~h}$ in DMEM supplemented with $1 \%$ fetal calf serum either with or without 3 $\mathrm{mM}$ ethylenediaminetetraacetic acid (EGTA). Two hours of incubation in media with EGTA (henceforward referred to as $\mathrm{Ca}^{2+}$-free media) was necessary to disrupt cell junctions, a process that was followed by observations with light field microscopy. Monolayers were then washed five times with DMEM, incubated in DMEM supplemented with $1 \%$ calf serum either with or without $10 \mathrm{nM}$ ouabain for $2 \mathrm{~h}$, fixed and processed by immunofluorescence as indicated above $[57,58]$.

\section{Immunoblot analysis}

For protein extraction, cells were washed three times with ice-cold PBS with $\mathrm{Ca}^{2+}$ and then incubated at $4{ }^{\circ} \mathrm{C}$ for 10 min with lysis buffer $(150 \mathrm{mM} \mathrm{NaCl}, 1 \%$ Nonidet P- $40,0.5 \%$ sodium deoxycholate, $0.1 \%$ SDS, and $50 \mathrm{mM}$ Tris pH 7.5). Then, the cellular extracts were centrifuged for $10 \mathrm{~min}$ at $17,000 \times \mathrm{g}$. The supernatant was recovered, and the cellular protein concentration was measured by a BCA assay (Cat. No. 23225, Pierce, Thermo Fisher). The cellular protein extracts were then boiled in Laemmli sample buffer (Cat. 1610737, Bio-Rad, Hercules, CA, USA), resolved by SDS-PAGE and transferred to PVDF membranes (Hybond-P; SigmaAldrich). The PVDF membranes were blocked overnight with 5\% BSA. Specific bands were detected with specific antibodies and chemiluminescence (ECL and Hiperfilm; Amersham). Resolved bands were analyzed with FIJI software. 


\section{Cellular Physiology Cell Physiol Biochem 2019;52:1381-1397 \\ \begin{tabular}{ll|l} 
and Biochemistry $10.33594 / 000000097$ & (c) 2019 The Author(s). Published by \\
Cell Physiol Biochem Press GmbH\&Co. KG
\end{tabular} \\ Castillo et al.: Ouabain Influences Adherens Junctions}

\section{Statistical Analysis}

Statistical analysis was performed with Prism 6 (GraphPad Software, San Diego CA). The results are expressed as the mean \pm SE. Statistical significance was estimated with a two-tailed Student's t-test or one-way ANOVA followed by Bonferroni's selected pairs comparison test $\left({ }^{*} \mathrm{P}<0.05,{ }^{* *} \mathrm{P}<0.01\right.$, and ${ }^{* * *} \mathrm{P}$ $<0.001)$. All experiments were repeated at least three times. The number of independent experiments is represented by $n$.

\section{Results}

Ouabain increases the amount of E-cadherin and $\beta$-catenin in the cell border and induces the translocation of $\beta$-catenin into the nucleus

We assessed the role of ouabain on the two most conspicuous molecular species of adherens junctions, E-cadherin and $\beta$-catenin. As expected, under the control conditions, both proteins were located at the perimeter of the cells (Fig. 1A and $\mathrm{C}$, white arrows). Exposure to ouabain increased the intensity of this signal for both proteins (Fig. 1B and D, white arrows), suggesting an increase in protein expression at the lateral plasma membrane. Ouabain also increased the intracellular signal of E-cadherin and $\beta$-catenin (Fig. 1B and D, white arrowheads) and induced the expression of E-cadherin in several basal locations (empty arrowhead in $B x-z$ image). Interestingly, the signal of $\beta$-catenin in the nucleus increased with ouabain (Fig. 1D, empty arrows). To confirm and measure these changes in expression, we prepared cellular and nuclear extracts of control and ouabain-incubated cells and performed immunoblots of both proteins (Fig. 1E). The amount of E-cadherin in the control condition was $0.76 \pm 0.06$ arbitrary units (a.u., Fig. 1G, first white column), and ouabain induced a statistically significant increase to $1.24 \pm 0.25$ a.u. (Fig. $1 \mathrm{E}$, first red column; $p=0.044, n=6$ ). A similar result was observed for the total cellular $(0.42 \pm 0.05$ a.u. in the control vs. $0.86 \pm$ 0.14 a.u. in ouabain-treated protein extracts, $p=0.0139, n=4)$ as well as nuclear $(1.00 \pm 0.00$ a.u. in the control vs. $1.30 \pm 0.08$ a.u. in nuclear extracts treated with ouabain, $p=0.0079, n$ = 3) $\beta$-catenin content. Therefore, hormonal ouabain concentrations upregulate adherens junction proteins and induce the translocation of $\beta$-catenin into the nucleus.

\section{$\mathrm{Na}^{+}, \mathrm{K}^{+}$-ATPase is the receptor of hormone ouabain}

To determine whether $\mathrm{Na}^{+}, \mathrm{K}^{+}$-ATPase mediates the adherens junction-enhancing effect of ouabain, we used R-MDCK, a cell clone of MDCK cells that express a mutant $\mathrm{Na}^{+}, \mathrm{K}^{+}$-ATPase $\alpha$-subunit with low affinity for this hormone [52, 53]. Fig. 2 shows that the immunofluorescence control pattern of E-cadherin (Fig. 2A) and $\beta$-catenin (Fig. 2C) did not change after incubation with $10 \mathrm{nM}$ ouabain (Fig. 2B and D). In Fig. 2E, we observed that the amount of the two proteins measured in Western blots did not show significant changes upon incubation with ouabain for cellular E-cadherin (1.00 \pm 0.12 a.u. in the control vs. 1.26 \pm 0.21 a.u. in ouabain-treated cells, $\mathrm{p}=0.3029, \mathrm{n}=6)$ and cellular $\beta$-catenin $(1.00 \pm 0.13$ a.u. in the control vs. $0.86 \pm 0.21$ a.u. in ouabain-treated cells, $p=0.3029, n=4$ ) or nuclear $\beta$-catenin $(1.00 \pm 0.11$ a.u. in the control vs. $0.81 \pm 0.08$ a.u. in ouabain-treated cells, $p=$ $0.2466, \mathrm{n}=3$ ). This confirms that $\mathrm{Na}^{+}, \mathrm{K}^{+}$-ATPase is the receptor of ouabain that modulates adherens junctions.

10 nM ouabain increases the translocation of $\gamma$-catenin into the nucleus but does not affect the translocation of $\mathrm{ZO}-1$ or $\mathrm{ZO}-2$

Fig. 1 shows that ouabain induced the translocation of $\beta$-catenin into the nucleus. It has been shown that several experimental conditions, such as subconfluence and wound healing, induce the displacement of other cytoplasmic proteins, such as ZONAB, ZO-1, ZO2, $\gamma$-catenin, etc., into the nucleus [59-62]. In this study, we investigated whether $10 \mathrm{nM}$ ouabain induces the translocation of other peripheral membrane proteins belonging to tight junctions. Fig. 3A shows a chicken fence pattern of ZO-1 and that this protein was absent in the nucleus. Ouabain did not change ZO-1 expression or localization (Fig. 3B). A similar 


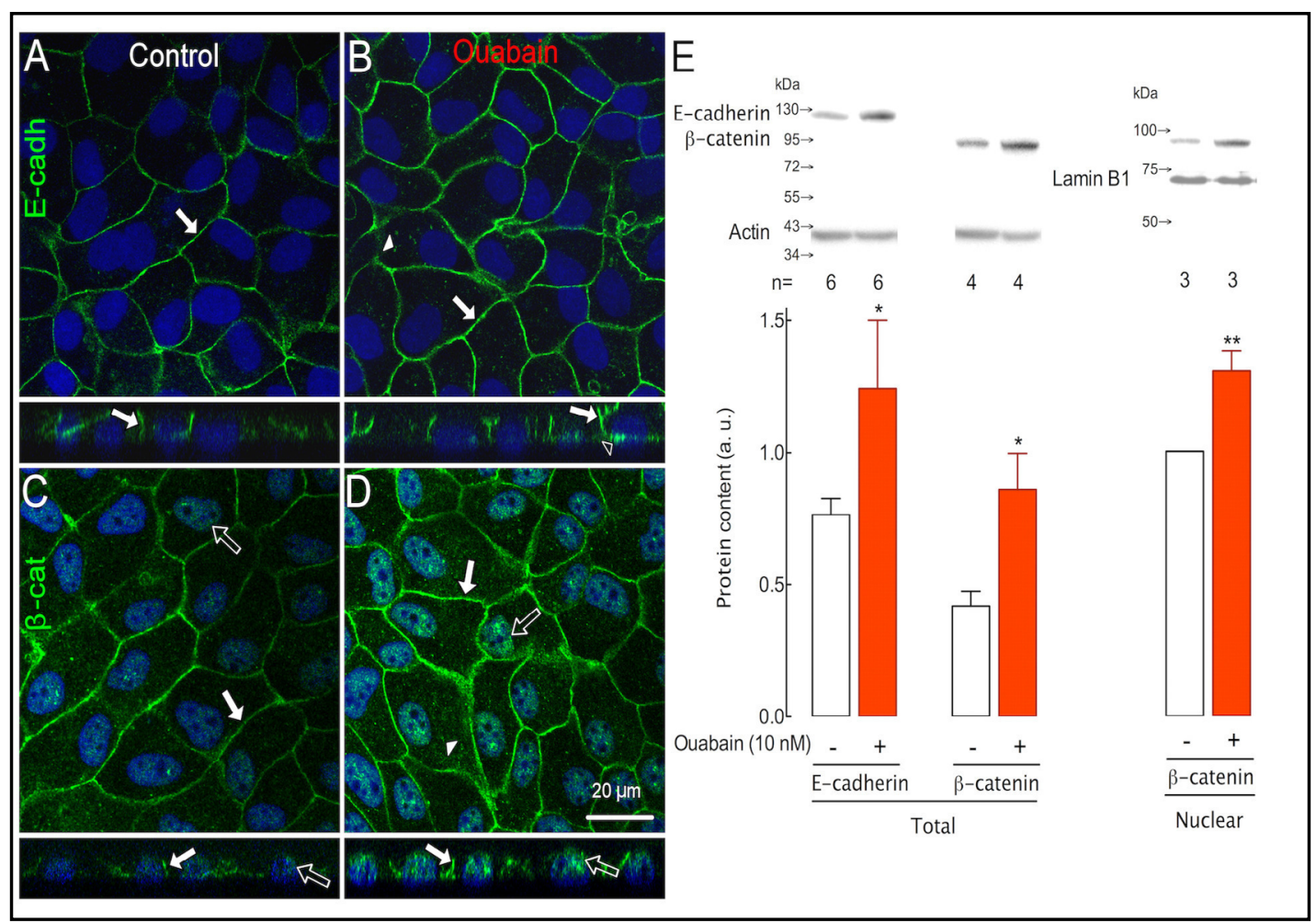

Fig. 1. Ouabain increases the expression of specific adherens junction proteins. Immunofluorescence of E-cadherin (E-cadh, A and B, green) or $\beta$-catenin ( $\beta$-cat, $C$ and D, green) in confluent monolayers of MDCK cells under control (A and C) and $10 \mathrm{nM}$ ouabain (B and D) conditions. Nuclei are stained in blue. Cell monolayers are observed in fluorescence images of single optical slices in the $x-y$ (upper) and $x-z$ (lower) orientations. In control cell monolayers, E-cadherin (A) and $\beta$-catenin (C) are distributed mainly in the periphery (white arrows). Eight hours of exposure to ouabain increased the amount of E-cadherin (B) and $\beta$-catenin (D) at the cell border and displaced $\beta$-catenin towards the nucleus (D, empty arrows). Ouabain induced the appearance of several basal locations of E-cadherin (empty arrowhead). Western blotting (E, above) and densitometric analysis (E, graph) of cellular or nuclear protein extracts normalized to actin or lamin B1 (E, above), respectively, showing the normal amount of both proteins (white bars) and the increased amount of proteins produced by ouabain (red bars) in cellular and nuclear extracts. $* \mathrm{P}<0.05, \mathrm{n}=$ $6-3,{ }^{* *} \mathrm{P}<0.01, \mathrm{n}=6-3$, t-test.

result was observed for ZO-2 (Fig. 3C vs D). However, $\gamma$-catenin (Fig. 3E) was expressed in the contact zone as well as in the nucleus (Fig. 3E), and ouabain increased the fluorescence signal both in the contact zone (Fig. 3F) and the nucleus (Fig. 3F, white arrows). $\gamma$-catenin increased in abundance with the addition of ouabain, as observed in the immunoblots of nuclear protein extracts (Fig. $3 \mathrm{H}, 1.00 \pm 0.00$ a.u. in control vs. $1.41 \pm 0.11$ a.u. with ouabain, $\mathrm{p}=0.0097, \mathrm{n}=3$ ) and, as expected, ZO-1 and ZO-2 were not detected (Fig. 3G). The cellular content of ZO-1 and ZO-2 in the cells remained unchanged with the addition of ouabain (Fig. 3H). However, the normal amount of $\gamma$-catenin $(0.99 \pm 0.03$ a.u.) increased a small but statistically significant amount with the addition of the hormone $(1.16 \pm 0.05$ a.u.). These results show that $10 \mathrm{nM}$ ouabain specifically induces the translocation of the peripheric adherens junction proteins $\beta$-catenin and $\gamma$-catenin into the nucleus.

$\beta$-catenin increases at the cell borders, and its translocation into the nucleus depends on $c$-Src and ERK1/2 activation

In previous studies, we observed that $10 \mathrm{nM}$ ouabain increased the degree of phosphorylation of c-Src and ERK1/2 [39]. Hence, to determine whether this signaling route is involved in the effect of ouabain on the translocation of $\beta$-catenin, we impaired 


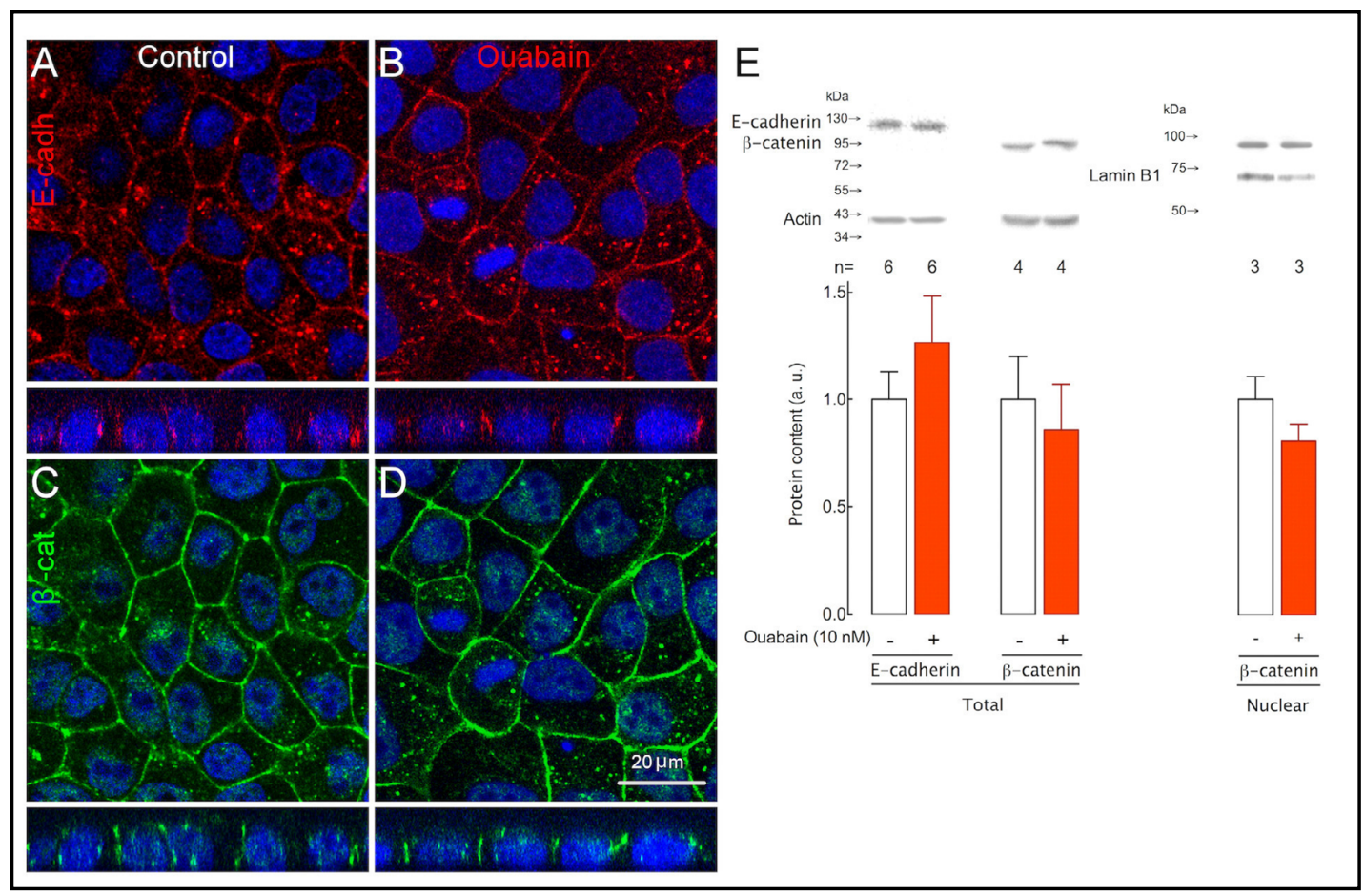

Fig. 2. $\mathrm{Na}^{+}, \mathrm{K}^{+}$-ATPase acts as an ouabain receptor for adherens junction regulation. Fluorescence images corresponding to single optical slices. Immunofluorescence of E-cadherin (E-cadh, A and B, red) or $\beta$-catenin ( $\beta$-cat, $C$ and D, green) in confluent monolayers of control MDCK cells (A and C) and MDCK cells incubated for $8 \mathrm{~h}$ in $10 \mathrm{nM}$ ouabain (B and D). Nuclei are stained in blue. Cell monolayers are observed in fluorescence images of single optical slices in the $\mathrm{x}-\mathrm{y}$ (upper) and $\mathrm{x}-\mathrm{z}$ (lower) orientations. R-MDCK cells express a mutant $\mathrm{Na}^{+}, \mathrm{K}^{+}$-ATPase with low affinity for ouabain. Western blotting (E, above) and densitometric analysis (E, graph) of cellular or nuclear protein extracts normalized to actin or lamin B1 (E, above), respectively, showing the protein content of control (white bars) and ouabain treated (red bars) cell monolayers. $n=6-3$, analyzed with t-test of ouabain vs. control.

the activation of c-Src and ERK1/2 with the inhibitors PP2 and PD98059, respectively. Fig. $4 \mathrm{~A}$ shows the typical control $\beta$-catenin immunofluorescence pattern, and $10 \mathrm{nM}$ ouabain induced a substantial increase in membrane and nuclear fluorescence signals (Fig. 4B). The pairs of images shown in Fig. 4C and $4 \mathrm{D}$ and Fig. $4 \mathrm{E}$ and $4 \mathrm{~F}$ are analogous to the conditions for the images shown in Fig. 4A and $4 \mathrm{~B}$ but in the presence of PP2 or PD, respectively. These inhibitors did not change $\beta$-catenin distribution and intensity but impaired the increases elicited by ouabain (Fig. 4C vs. 4D and Fig. 4E vs. 4F). The increase in the nuclear content of $\beta$-catenin was quantified for the fluorescent images (Fig. 4G), and we found that the fluorescent signal increased from $1.00 \pm 0.06$ a.u. in the control to $3.25 \pm 0.24$ a.u. in ouabaintreated cells $(\mathrm{p}<0.0001, \mathrm{n}=49-47$ nuclei from 3 independent experiments). The inhibition of both c-Src and ERK1/2 activity with PP2 and PD, respectively, impaired the increase in the intensity of the fluorescent signal triggered by ouabain, resulting in values of $1.30 \pm 0.09$ a.u. and $0.98 \pm 0.07$ a.u., respectively, which were significantly less than the signal induced by ouabain itself $(\mathrm{p}<0.0001$ for both cases, $\mathrm{n}=58$ and 47 nuclei from 3 independent experiments, respectively). We also demonstrated that the increase of $\beta$-catenin in cellular protein extracts induced upon ouabain treatment (Fig. 1 and Fig. 4I, from $1.00 \pm 0.06$ to 1.51 \pm 0.17 a. u.) required c-Src and ERK1/2 activation (Fig. 4I) because PP2 and PD blocked the response to yield fluorescence intensities of $1.025 \pm 0.09$ a.u. and $1.05 \pm 1.14$ a.u., respectively $(\mathrm{p}=0.0185 ; \mathrm{n}=7)$. Therefore, our results demonstrated that ouabain activates the kinases c-Src and ERK1/2 to induce the translocation of $\beta$-catenin into the nucleus and increases the cellular adherens contacts. 


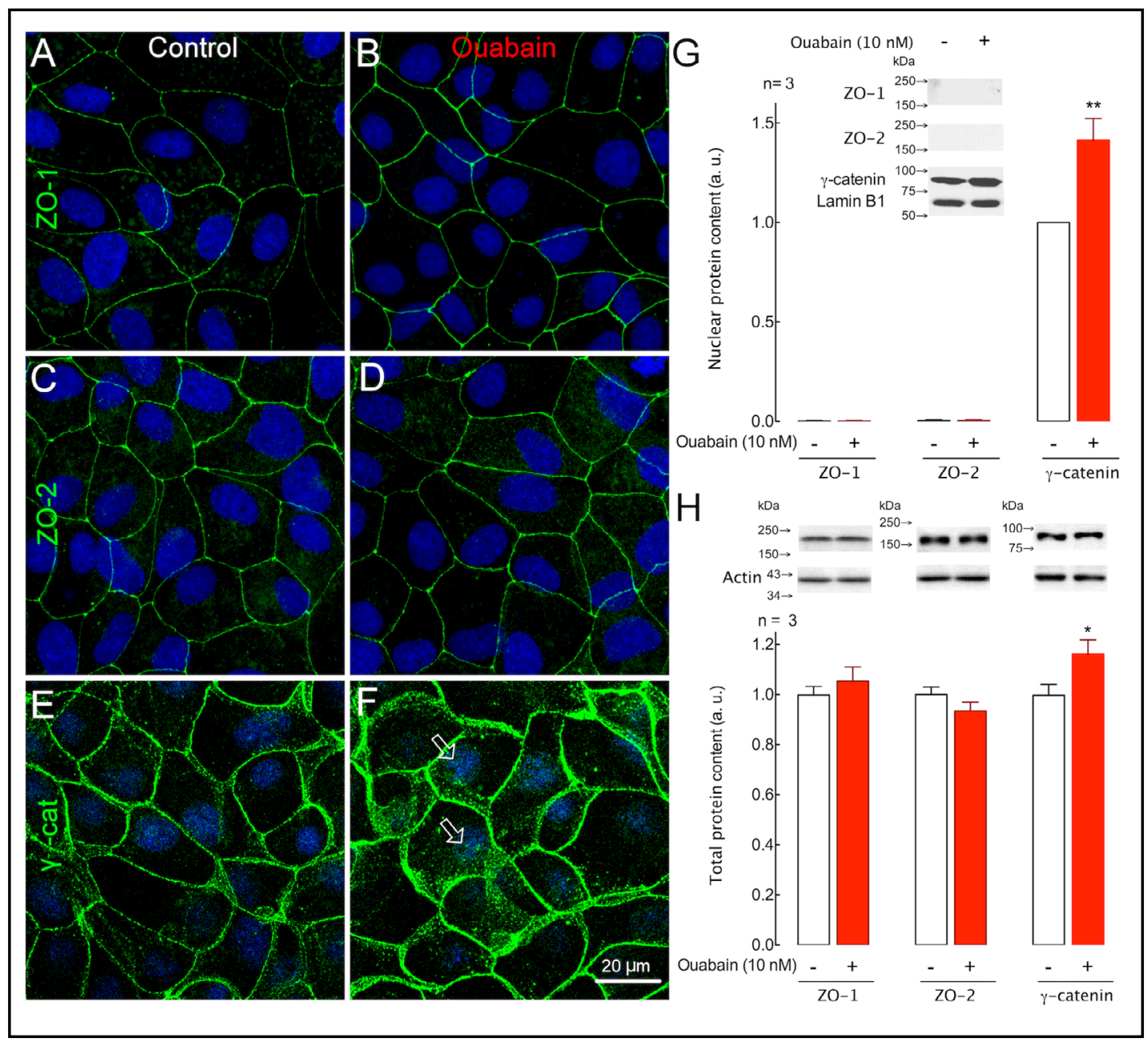

Fig. 3. Ouabain induces $\gamma$-catenin translocation into the nucleus. Images show the projection of 30 to 40 optical slices. Immunofluorescence of ZO-1 (A and B, green), ZO-2 (C and D, green) and $\gamma$-catenin (E and $\mathrm{F}$, green) in confluent monolayers of control MDCK cells (A, C and E) and MDCK cells treated with $10 \mathrm{nM}$ ouabain (B, D and F). Nuclei are stained in blue. The white arrows in F point to nuclear $\gamma$-catenin. (G) Western blotting and densitometric analysis of ZO-1, ZO-2 and $\gamma$-catenin in nuclear protein extracts of control cells (white bars) or cells incubated for $8 \mathrm{~h}$ with $10 \mathrm{nM}$ ouabain (red bars); gel loading was normalized to lamin B1. (H) Western blotting and densitometric analysis of ZO-1, ZO-2 and $\gamma$-catenin in cellular and nuclear protein extracts, normalized to actin or lamin B1, respectively, for control (white bars) and ouabain-treated (red bars) cell monolayers. ${ }^{*} \mathrm{P}<0.05$, $^{*} \mathrm{P}<0.01, \mathrm{n}=3$, t-test of ouabain vs control.

\section{The increase in E-cadherin depends on c-Src and ERK1/2 activation}

Then, we investigated whether ouabain activates the kinases c-Src and ERK1/2 to increase E-cadherin at the cell borders. Fig. 5A shows the control E-cadherin pattern in a cell monolayer. Ouabain $(10 \mathrm{nM})$ induced an increase in the E-cadherin signal at the plasma membrane (Fig. 5B). Images of Fig. 5C and D and images of Fig. 5E and F are similar to the images of. Fig. 5A and B but incubated with PP2 or PD, respectively. Both inhibitors did not affect E-cadherin localization ( $C$ and $E$ ) but inhibited the effect of ouabain (D and F). Therefore, ouabain-induced increases in E-cadherin are dependent on c-Src and ERK1/2. Fig. 5G shows the statistical analysis of the total cellular content of E-cadherin measured by Western blotting, confirming the dependence of E-cadherin levels on the activation of c-Src and ERK1/2 kinases, with values of $0.92 \pm 0.13$ and $1.02 \pm 0.15$ a.u., respectively, which are significantly less $(\mathrm{P}=0.0024)$ than that with only ouabain $(1.00 \pm 0.00)$. 


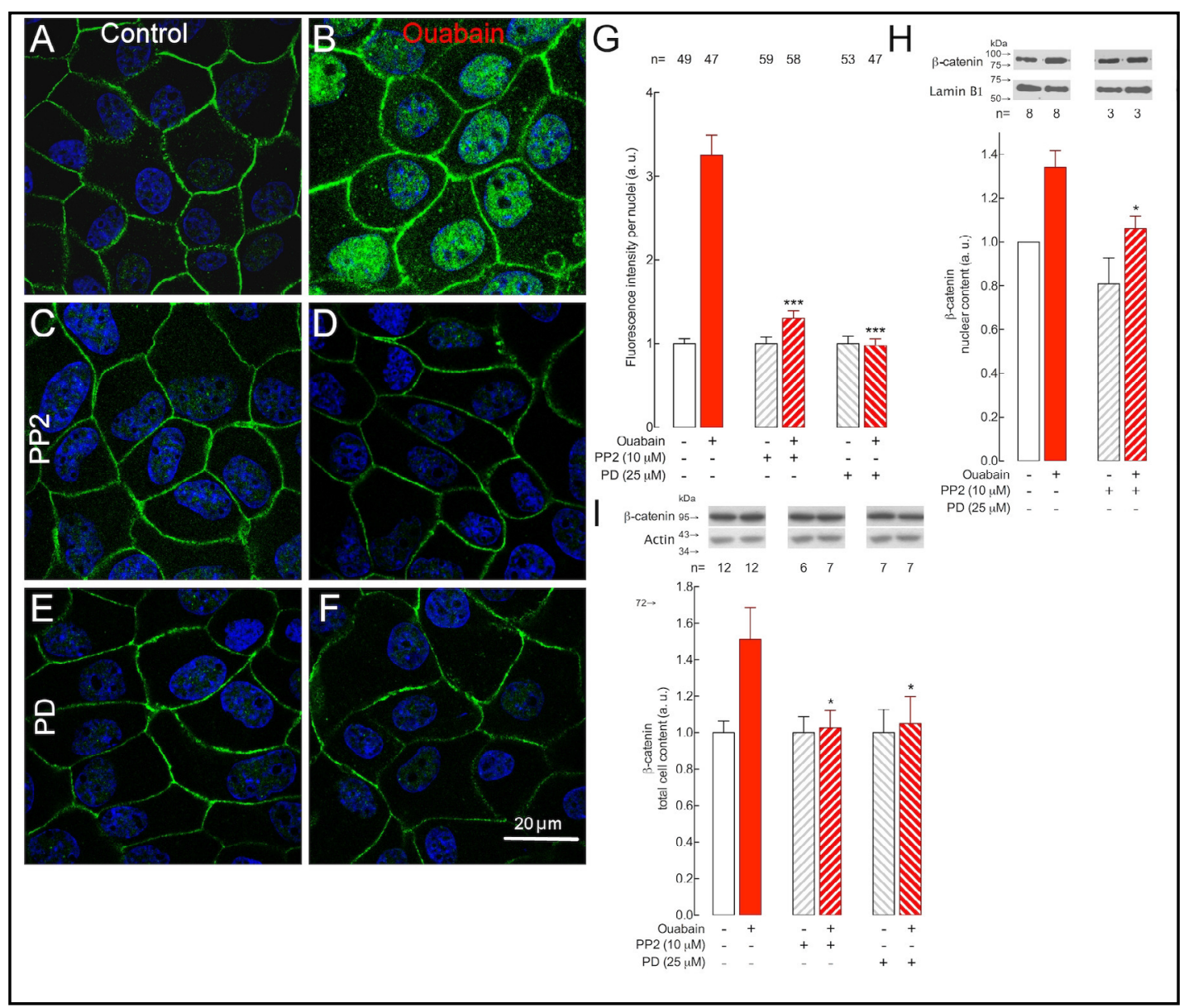

Fig. 4. Ouabain modulates $\beta$-catenin via c-Src and ERK1/2 activation. c-Src and ERK1/2 activity was impaired by $10 \mu \mathrm{M}$ PP2 and $25 \mu \mathrm{M}$ PD98059 (PD), respectively. (A) A control monolayer and (B) a monolayer treated with $10 \mathrm{nM}$ ouabain for $8 \mathrm{~h}$. (C and D) are monolayers analogous to (A and B), respectively, except that these monolayers were pretreated for $1 \mathrm{~h}$ and throughout the experiment with PP2. (E and F) are analogous to (A and B) except that these monolayers were pretreated for $1 \mathrm{~h}$ and throughout the experiment with PD. (G) Corresponding statistical analysis of the average fluorescence intensity per nucleus. Bars from left to right: white bars control cells, red bars ouabain-treated cells, cells pretreated with PP2, cells pretreated with PP2 for $1 \mathrm{~h}$ before adding ouabain, cells pretreated with PD, cells pretreated with PD before adding ouabain, and cells remaining in the presence of this substance. Abundance of $\beta$-catenin in $(H)$ nuclear protein extracts and (I) cellular protein extracts. Bars shown in (H) are analogous to bars shown in (G). The $n$ in (G) indicates the total number of nuclei measured in images obtained from four independent experiments, and in $(\mathrm{H})$ and $(\mathrm{I})$, the $\mathrm{n}$ indicates the number of independent Western blotting experiments. ${ }^{*} \mathrm{P}<0.05$, ${ }^{* *} \mathrm{P}<0.01$, *** $\mathrm{p} \leq 0.001$. Data were analyzed by one-way ANOVA of ouabain plus inhibitor-treated cells (PP2 slashed and PD back-slashed red columns) vs. ouabain-treated cells (red column). In Fig. 4G, n represents the number of nuclei observed in 3 independent experiments.

\section{Ouabain accelerates the assembly of adherens junctions}

We speculated whether ouabain accelerates adherens junction formation. To investigate this possibility, we used a calcium switch protocol. Fig. 6 illustrates an MDCK monolayer under control conditions (Fig. 6A) showing the typical "chicken fence" yellow pattern of E-cadherin (green) and $\beta$-catenin (red) colocalization in the plasma membrane of mature epithelial cells. Removal of $\mathrm{Ca}^{2+}$ induced the disassembly of the adherens junctions and endocytosis of its molecular components, as indicated by the cytoplasmic fluorescent signals of E-cadherin and $\beta$-catenin (Fig. 6B). The addition of $\mathrm{Ca}^{2+}$ induced the expression of both proteins in the cell borders (Fig. 6C), indicating the reformation of adherens junctions. Ouabain with $\mathrm{Ca}^{2+}$ 


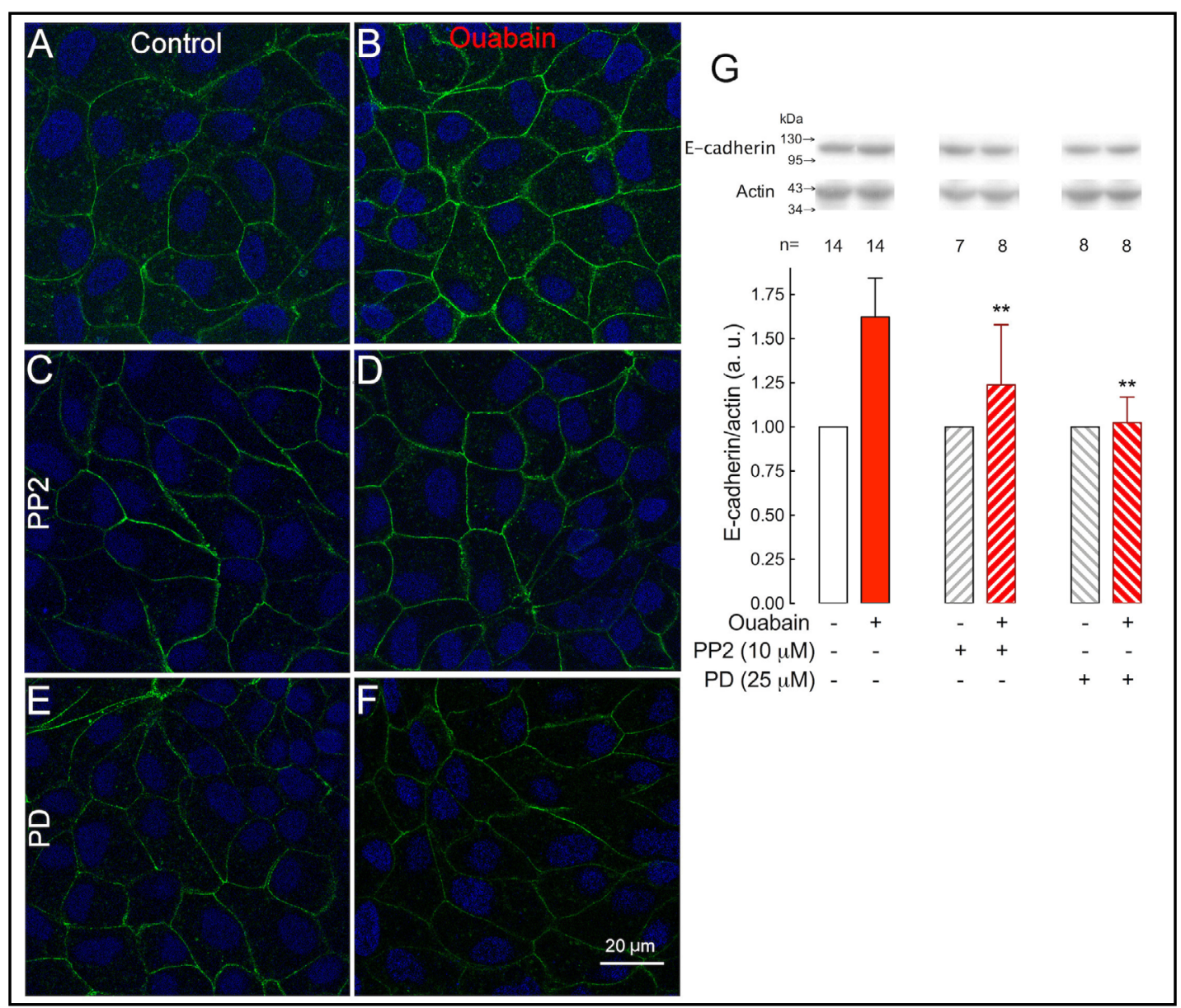

Fig. 5. The increase in E-cadherin is dependent on c-Src and ERK1/2 signaling. Immunofluorescence images show E-cadherin in green and nuclei stained in blue in the single optical slice with the highest fluorescent signal of the chicken fence pattern. (A) Control cells; and (B) cells treated with $10 \mathrm{nM}$ ouabain for $8 \mathrm{~h}$. ( $C$ and D) are analogous to (A and B), respectively, except that these monolayers were pretreated for $1 \mathrm{~h}$ and throughout the experiment with the c-Src inhibitor PP2. (E and F) are analogous to (A and B), except that these monolayers were pretreated for $1 \mathrm{~h}$ and throughout the experiment with PD. (G) Corresponding statistical analysis of the cellular E-cadherin content. White bars correspond to the control cells, and red bars correspond to ouabain-treated cells. Slashed and back-slashed bars correspond to cells treated with PP2 or $\mathrm{PD}$, respectively. ${ }^{* * *} \mathrm{P} \leq 0.001,{ }^{* *} \mathrm{P}<0.01,+^{*} \mathrm{p} \leq 0.5$. The $\mathrm{n}$ indicates the number of independent experiments. Data were analyzed by one-way ANOVA of ouabain plus inhibitor-treated cells (slashed and back-slashed red columns) vs. ouabain-treated cells (red column).

induced increased expression of the proteins at cell-cell contacts compared to $\mathrm{Ca}^{2+}$ alone (Fig. 6D), indicating accelerated adherens junction formation. Surprisingly, PP2 by itself induced a similar effect as ouabain (Fig. 6E) but inhibited the effect of ouabain (Fig. 6F). Furthermore, PD did not exert an effect by itself but inhibited the effect of ouabain. The graphs in Fig. 6 show the quantification of the length E-cadherin (Fig. 6I) and $\beta$-catenin (Fig. 6J) fluorescent signals in cell-cell contacts. Clearly, ouabain induced a statistically significant increase in the length of the linear signal of E-cadherin (Fig. 6I) from $35.08 \pm 1.74$ to $68.79 \pm$ $1.92 \mu \mathrm{m}(\mathrm{p}=0.0001$ ) and of $\beta$-catenin (Fig. 6J) from $45.04 \pm 2.086$ to $65.09 \pm 1.69$, which was produced by the addition of $\mathrm{Ca}^{2+}$, and PP2 and PD inhibited the effects of ouabain, which led to significantly lower length values for E-cadherin (47.35 \pm 9.15 and $50.35 \pm 7.25$, respectively) and $\beta$-catenin ( $48.43 \pm 9.62$ and $52.92 \pm 7.86$, respectively). These observations prove that $10 \mathrm{nM}$ ouabain accelerates the assembly of adherens junctions through a signaling pathway that includes c-Src and ERK1/2 kinases. 


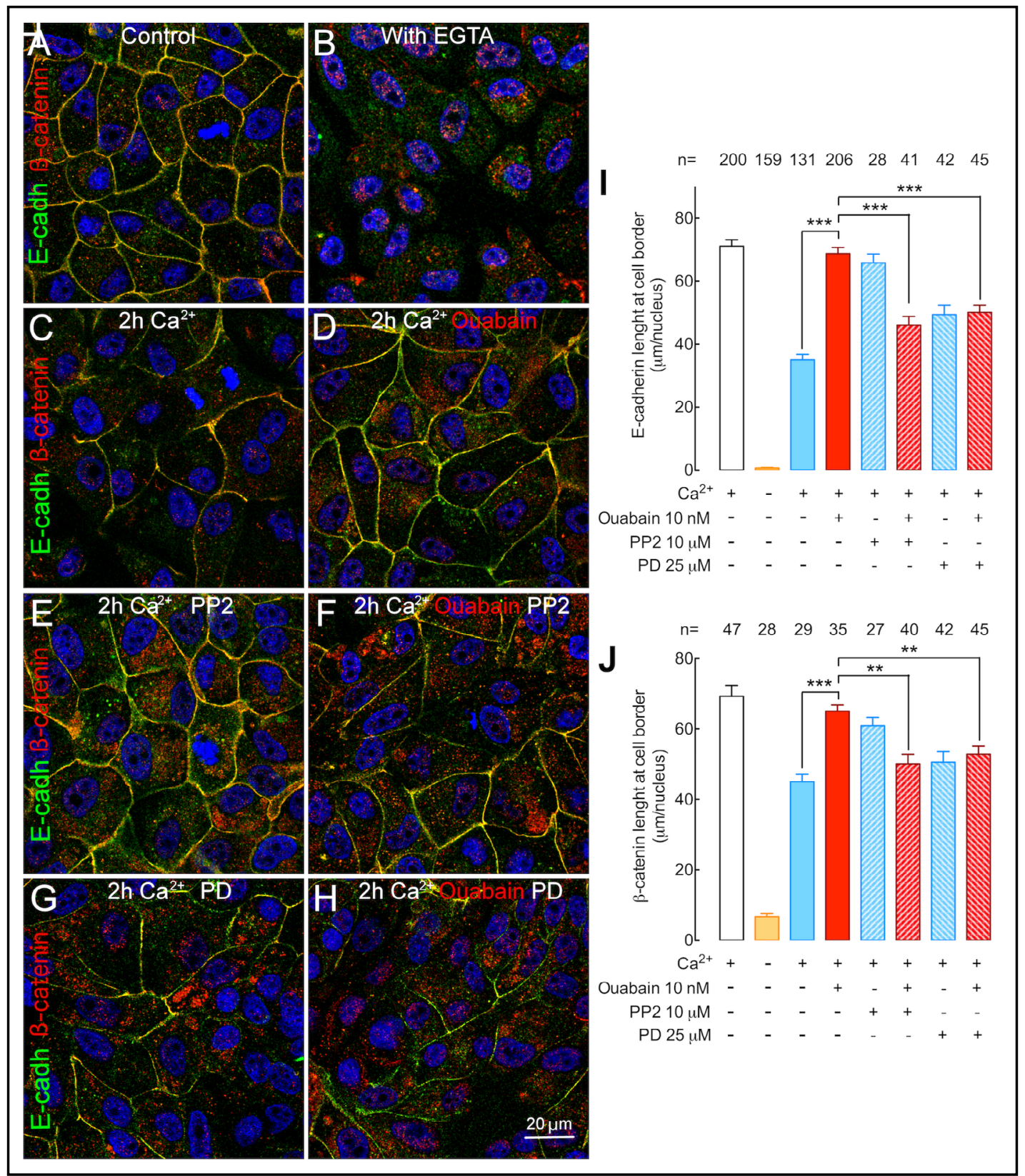

Fig. 6. Ouabain accelerates adherens junction formation in a c-Src and ERK1/2 independent manner. (A) Distribution of E-cadherin (green) and $\beta$-catenin (red) in control cells. (B) Cells without calcium for $2 \mathrm{~h}$. (C and D) Cells that remained without calcium for $2 \mathrm{~h}$, and at that moment, were switched to $\mathrm{Ca}^{2+}$ containing medium for an additional $2 \mathrm{~h}$ in the absence (C) and in the presence (D) of ouabain. (E) corresponds to cells switched to $\mathrm{Ca}^{2+}$ in the presence of PP2. (F) Cells switched to $\mathrm{Ca}^{2+}$ in the presence of PP2 and ouabain. (G) corresponds to cells switched to $\mathrm{Ca}^{2+}$ in the presence of $\mathrm{PD}$, and $(\mathrm{H})$ corresponds to cells exposed to $\mathrm{Ca}^{2+}, \mathrm{PD}$ and ouabain. The images show the total projection of 40 to 60 optical slices. Statistical analysis of the linear fluorescent signal of (I) E-cadherin and (J) $\beta$-catenin at the cell borders during $\mathrm{Ca}^{2+}$ removal and replenishment in the absence or presence of the c-Src or ERK1/2 inhibitors. The white bar corresponds to the control cells, the yellow bar corresponds to the cells incubated for $2 \mathrm{~h}$ with EGTA, the blue bars correspond to cells switched to $\mathrm{Ca}^{2+}$, the red bars correspond to cells switched to $\mathrm{Ca}^{2+}$ in the presence of ouabain, the slashed bars indicate cells incubated with PP2 and the back-slashed bars indicate cells incubated with PD. The $\mathrm{n}$ represents the number of cells from 3 to 7 independent experiments analyzed by one-way ANOVA with Bonferroni's selected pairs comparison. 


\section{Cellular Physiology Cell Physiol Biochem 2019;52:1381-1397 \\ \begin{tabular}{ll|l} 
and Biochemistry $10.33594 / 000000097$ & (c) 2019 The Author(s). Published by \\
Cublished online: 11 May 2019 & Cell Physiol Biochem Press GmbH\&Co. KG
\end{tabular} \\ Castillo et al.: Ouabain Influences Adherens Junctions}

\section{Discussion}

Following our previous systematic approach to investigate the control of cell adhesion by ouabain, in this study, we investigated the effect of $10 \mathrm{nM}$ ouabain on other intercellular contact, the adherens junction. We studied E-cadherin, ß-catenin and $\gamma$-catenin localization by immunofluorescence and measured their amount in cells and nuclei by immunoblotting. We have previously shown that $100 \mathrm{nM}$ ouabain induces the translocation of $\beta$-catenin into the nucleus $[31,49]$. The results presented in this study imply that $10 \mathrm{nM}$ ouabain induces the same phenomenon (Fig. 1); we extended the observation to $\gamma$-catenin (Fig. 3 ) and showed that the integral membrane protein of the adherens junction, E-cadherin, increases as well (Fig. 1). An increased abundance of adherens junction proteins in the plasma membrane would conceivably strengthen intercellular adhesion and, therefore, the transporting epithelial phenotype. Consistent with this possibility, it has been shown that ouabain increases the degree of tight junction sealing in MDCK cells [39], accelerates cellular polarity development, as indicated by a more rapid ciliation in MDCK cells [42], and increases vectorial transport of $\mathrm{Na}^{+}$in LLCPK1 cells by inducing increase apical expression of the $\mathrm{Na}^{+} / \mathrm{H}^{+}$-exchanger [63]. Therefore, hormonal concentrations of ouabain seem to potentiate cell adhesion and polarity, similar to other physiological regulators of the tight junction, such as epidermal growth factor, which changes the molecular composition of the tight junction and increases its degree of sealing and the transepithelial transport of $\mathrm{Na}^{+}$[64]. Interestingly, high concentrations of ouabain are toxic in humans and induce the opposite effect as the hormonal concentration of $10 \mathrm{nM}$; high concentrations promote the endocytosis and lysosomal degradation of cell adhesion molecules and the detachment and death of epithelial cells $[37,38,66]$. Nevertheless, at either low or high concentrations, ouabain plays a crucial role in the regulation of cell contacts.

To investigate how ouabain exerts its effects, we used a mutant MDCK clone that expresses a $\mathrm{Na}^{+}, \mathrm{K}^{+}$-ATPase $\alpha$-subunit with low affinity for ouabain $[52,53]$. Ouabain binds to $\mathrm{Na}^{+}, \mathrm{K}^{+}$-ATPase with an affinity that depends on the isoform of the $\alpha$-subunit that is expressed [67]. There is, however, a second receptor that binds ouabain at a high $\mathrm{K}^{+}$concentration, where ouabain cannot bind to $\mathrm{Na}^{+}, \mathrm{K}^{+}$-ATPase [68]. Nevertheless, the lack of response in R-MDCK cells makes it evident that ouabain must bind to $\mathrm{Na}^{+}, \mathrm{K}^{+}$-ATPase to upregulate adherens junction proteins and induce the translocation of $\beta$-catenin and $\gamma$-catenin into the nucleus.

The binding of a ligand to its receptor often triggers the displacement of specific peripheral proteins of cell adhesions towards the nucleus, such as ZONAB, ZO-1, ZO-2 and $\gamma$-catenin, which form nuclear adhesion complexes (NACos) [69]. We investigated whether ouabain induces the translocation of other peripheral membrane proteins belonging to cell junctions. The translocation into the nucleus is specific for $\beta$-catenin and $\gamma$-catenin, such as ZO-1 and ZO-2, which remain in the junctions despite ouabain treatment (Fig. 3). These results indicate that ouabain specifically induces the translocation of membrane-associated proteins of the adherens junctions but not of the tight junctions. These results also show that ouabain exerts its regulation on tight junctions through the modification of integral membrane proteins of the claudin family but not of the membrane-associated proteins ZO-1 and $\mathrm{ZO}-2$.

The use of low ouabain concentrations highlighted the role of $\mathrm{Na}^{+}, \mathrm{K}^{+}$-ATPase as a receptor. It has been shown that upon ouabain binding, $\mathrm{Na}^{+}, \mathrm{K}^{+}$-ATPase often activates the c-SrcERK1/2 pathway for processes as diverse as inducing cell proliferation, increasing sealing or the degradation of tight junctions depending on the concentration of ouabain, or promoting hypertrophy of the kidney $[22,38,39,70]$. Our results show that ouabain also upregulates adherens junctions (Fig. 4 and 5). It is hypothesized that ouabain activates a common central signaling regulatory pathway for all intercellular contacts that share the same location in the lateral membrane and cooperate to increase cell-cell adhesion. Nevertheless, it is also clear that each intercellular junction may have specific regulatory pathways for some components. 


\section{Cellular Physiology Cell Physiol Biochem 2019;52:1381-1397 \\ \begin{tabular}{c|c|c} 
DOl: 10.33594/000000097 & $\begin{array}{l}\text { O } 2019 \text { The Author(s). Published by } \\
\text { Cell Physiol Biochem Press GmbH\&Co. KG }\end{array}$
\end{tabular}

To study the possible mechanism of the regulation of adherens junction formation by ouabain, we used a rapid $\mathrm{Ca}^{2+}$ removal and restoration method $[57,58] . \mathrm{Ca}^{2+}$ acts on the extracellular side of the plasma membrane to trigger the formation of tight junctions [7173], a process that requires the previous establishment of adherens junctions [74]. Ouabain accelerates the localization of E-cadherin and $\beta$-catenin at nascent adherent junctions (Fig. 6). It has been shown that the restoration of adherens and tight junctions after $\mathrm{Ca}^{2+}$ addition does not require protein synthesis but only protein relocalization [57] and that the expression of a suitable level of E-cadherin in the plasma membrane depends on balanced protein traffic [75]. Therefore, ouabain either accelerates the delivery of protein components to adherens junctions that are in formation or stabilizes the components of adherens junctions in cell-cell contacts.

The function of the $\beta$-catenin and $\gamma$-catenin translocated into the nucleus as a result of ouabain treatment is unknown, although it correlates with the transcription and expression of claudins and the increase in the transepithelial electrical resistance and may be necessary for these processes. Increased $\beta$-catenin in the nucleus is a classical signal for proliferation [48]; however, under the conditions used in this study, this proliferation signal could not operate because cells were confluent, and contact inhibition was activated. Therefore, it might be possible that nuclear $\beta$-catenin and $\gamma$-catenin activate a pathway that favors epithelial differentiation.

\section{Conclusion}

For the first time, we demonstrated that $10 \mathrm{nM}$ ouabain regulates adherens junctions. These results are consistent with our working hypothesis that one of the physiological functions of ouabain at hormonal concentrations is to modulate cell-cell contacts.

\section{Acknowledgements}

We thank Elizabeth del Oso and Érika del Oso for their administrative help. We also thank M.C. Iván Galván from the LaNSE (National Laboratories of Experimental Services) unit of confocal and multiphotonic microscopy for his technical assistance, Raúl Bonilla for immunoblotting advice, Ms. Teresa Avelino, Mr. Javier Soriano and Mr. Eduardo Méndez for their technical support. This work was supported by the National Research Council of Mexico (Conacyt).

\section{Disclosure Statement}

We declare that we have no conflicts of interest.

\section{References}

1 Hamlyn JM, Blaustein MP, Bova S, DuCharme DW, Harris DW, Mandel F, Mathews WR, Ludens JH: Identification and characterization of a ouabain-like compound from human plasma. Proc Natl Acad Sci U S A 1991;88:6259-6263.

2 Lichtstein D, Steinitz M, Gati I, Samuelov S, Deutsch J, Orly J: Biosynthesis of digitalis-like compounds in rat adrenal cells: hydroxycholesterol as possible precursor. Life Sci 1998;62:2109-2126.

3 Perrin A, Brasmes B, Chambaz EM, Defaye G: Bovine adrenocortical cells in culture synthesize an ouabainlike compound. Mol Cell Endocrinol 1997;126:7-15.

- 4 Qazzaz HM, Cao Z, Bolanowski DD, Clark BJ, Valdes R: De Novo Biosynthesis and Radiolabeling of Mammalian Digitalis-Like Factors. Clin Chem 2004;50:612-620. 


\section{Cellular Physiology Cell Physiol Biochem 2019;52:1381-1397 \begin{tabular}{ll|l|l} 
DOI: 10.33594/000000097 & C 2019 The Author(s). Published by \\
\hline
\end{tabular} and Biochemistry Published online: 11 May 2019 Cell Physiol Biochem Press GmbH\&Co. KG \\ Castillo et al.: Ouabain Influences Adherens Junctions}

- 5 Murrell JR, Randall JD, Rosoff J, Zhao JL, Jensen RV, Gullans SR, Haupert GT Jr: Endogenous ouabain: Upregulation of steroidogenic genes in hypertensive hypothalamus but not adrenal. Circulation 2005;112:1301-1308.

- 6 Bauer N, Müller-Ehmsen J, Krämer U, Hambarchian N, Zobel C, Schwinger RH, Neu H, Kirch U, Grünbaum EG, Schoner W: Ouabain-Like Compound Changes Rapidly on Physical Exercise in Humans and Dogs. Hypertension 2005;45:1024-1028.

- 7 Gottlieb SS, Rogowski AC, Weinberg M, Krichten CM, Hamilton BP, Hamlyn JM: Elevated concentrations of endogenous ouabain in patients with congestive heart failure. Circulation 1992;86:420-425.

- 8 Nesher M, Dvela M, Igbokwe VU, Rosen H, Lichtstein D: Physiological roles of endogenous ouabain in normal rats. Am J Physiol - Hear Circ Physiol 2009;297:H2026-H2034.

- 9 Aperia A, Holtbäck U, Syrén ML, Svensson LB, Fryckstedt J, Greengard P: Activation/deactivation of renal $\mathrm{Na}+\mathrm{K}(+)$-ATPase: a final common pathway for regulation of natriuresis. FASEB J 1994;8:436-439.

10 Moreth K, Kuske R, Renner D, Schoner W: Blood pressure in essential hypertension correlates with the concentration of a circulating inhibitor of the sodium pump. Klin Wochenschr 1986;64:239-244.

11 Schoner W, Bauer N, Müller-Ehmsen J, Krämer U, Hambarchian N, Schwinger R, Moeller H, Kost H, Weitkamp C, Schweitzer T, Kirch U, Neu H, Grünbaum EG: Ouabain as a mammalian hormone. Ann NY Acad Sci 2003;986:678-684.

- 12 Schoner W, Scheiner-Bobis G: Endogenous Cardiac Glycosides: Hormones Using the Sodium Pump as Signal Transducer. Semin Nephrol 2005;25:343-351.

- 13 Fedorova OV, Shapiro JI, Bagrov AY: Endogenous cardiotonic steroids and salt-sensitive hypertension. Biochim Biophys Acta - Mol Basis Dis 2010;1802:1230-1236.

- 14 Kometiani P, Li J, Gnudi L, Kahn BB, Askari A, Xie Z: Multiple signal transduction pathways link Na+/ $\mathrm{K}+$-ATPase to growth-related genes in cardiac myocytes. The roles of Ras and mitogen-activated protein kinases. J Biol Chem 1998;273:15249-15256.

- 15 Rayson BM: Calcium: a mediator of the cellular response to chronic $\mathrm{Na}+/ \mathrm{K}(+)$-ATPase inhibition. J Biol Chem 1993;268:8851-8854.

16 Tian J, Li X, Liang M, Liu L, Xie JX, Ye Q, Kometiani P, Tillekeratne M, Jin R, Xie Z: Changes in sodium pump expression dictate the effects of ouabain on cell growth. J Biol Chem 2009;284:14921-14929.

17 Orlov SN, Thorin-Trescases N, Kotelevtsev S V, Tremblay J, Hamet P: Inversion of the intracellular Na+/ $\mathrm{K}+$ ratio blocks apoptosis in vascular smooth muscle at a site upstream of Caspase-3. J Biol Chem 1999;274:16545-16552.

- 18 Aizman O, Uhlen P, Lal M, Brismar H, Aperia A: Ouabain, a steroid hormone that signals with slow calcium oscillations. Proc Natl Acad Sci 2001;98:13420-13424.

- 19 Li J, Khodus GR, Kruusmägi M, Kamali-Zare P, Liu XL, Eklöf AC, Zelenin S, Brismar H, Aperia A: Ouabain protects against adverse developmental programming of the kidney. Nat Commun 2010;1:42.

- 20 Khodus GR, Kruusmägi M, Li J, Liu XL, Aperia A: Calcium signaling triggered by ouabain protects the embryonic kidney from adverse developmental programming. Pediatr Nephrol 2011;26:1479-1482.

- 21 Burlaka I, Nilsson LM, Scott L, Holtbäck U, Eklö F AC, Fogo AB, Brismar H, Aperia A: Prevention of apoptosis averts glomerular tubular disconnection and podocyte loss in proteinuric kidney disease. Kidney Int 2016;90:135-148.

22 Wang H, Haas M, Liang M, Cai T, Tian J, Li S, Xie Z: Ouabain Assembles Signaling Cascades through the Caveolar Na + /K + -ATPase. J Biol Chem 2004;279:17250-17259.

23 Soltoff SP, Hedden L: Regulation of ERK1/2 by ouabain and Na-K-ATPase-dependent energy utilization and AMPK activation in parotid acinar cells. Am J Physiol Cell Physiol 2008;295:C590-C599.

24 Gloor S, Antonicek H, Sweadner KJ, Pagliusi S, Frank R, Moos M, Schachner M: The adhesion molecule on glia (AMOG) is a homologue of the beta subunit of the Na,K-ATPase. J Cell Biol 1990;110:165-174.

25 Shoshani L, Contreras RGRG, Roldán ML, Moreno J, Lázaro A, Balda MS, Cereijido M: The polarized expression of $\mathrm{Na}+, \mathrm{K}+-\mathrm{ATPase}$ in epithelia depends on the association between beta-subunits located in neighboring cells. Mol Biol Cell 2005;16:1071-1081.

- 26 Padilla-Benavides T, Roldán ML, Larre I, Flores-Benitez D, Villegas-Sepúlveda N, Contreras RG, Cereijido M, Shoshani L: The polarized distribution of $\mathrm{Na}+\mathrm{K}+-\mathrm{ATPase}$ : role of the interaction between $\{$ beta\} subunits. Mol Biol Cell 2010;21:2217-2225. 


\section{Cellular Physiology Cell Physiol Biochem 2019;52:1381-1397 \begin{tabular}{ll|l|l}
\hline DOI: 10.33594/000000097 & (O) 2019 The Author(s). Published by \\
and Biochemistry
\end{tabular} and Biochemistry Published online: 11 May 2019 Cell Physiol Biochem Press GmbH\&Co. KG

27 Contreras RG, Lázaro A, Bolivar JJ, Flores-Maldonado C, Sánchez SH, González-Mariscal L, García-Villegas MR, Valdés J, Cereijido M: A novel type of cell-cell cooperation between epithelial cells. J Membr Biol 1995;145:305-310.

- 28 Hammerton RW, Krzeminski KA, Mays RW, Ryan TA, Wollner DA, Nelson WJ: Mechanism for regulating cell surface distribution of Na+,K(+)-ATPase in polarized epithelial cells. Science 1991;254:847-850.

29 Cereijido M, Contreras RG, Shoshani L, Larre I: The Na+-K+-ATPase as self-adhesion molecule and hormone receptor. Am J Physiol Cell Physiol 2012;302:C473-C481.

- 30 Koefoed-Johnsen V, Ussing HH: The Nature of the Frog Skin Potential. Acta Physiol Scand 1958;42:298-308.

- 31 Cereijido M, Contreras RG, Shoshani L: Cell adhesion, polarity, and epithelia in the dawn of metazoans. Physiol Rev 2004;84:1229-1262.

32 Vagin 0, Tokhtaeva E, Sachs G: The Role of the $\beta$-Subunit of the Na,K-ATPase and Its Glycosylation in CellCell Adhesion. J Biol Chem 2006;281:39573-39587.

33 Tokhtaeva E, Sachs G, Sun H, Dada LA, Sznajder JI, Vagin O: Identification of the amino acid region involved in the intercellular interaction between the 1 subunits of Na+/K+-ATPase. J Cell Sci 2012;125:1605-1616.

34 Rajasekaran SA, Palmer LG, Moon SY, Peralta Soler A, Apodaca GL, Harper JF, Zheng Y, Rajasekaran AK: $\mathrm{Na}$,K-ATPase activity is required for formation of tight junctions, desmosomes, and induction of polarity in epithelial cells. Mol Biol Cell 2001;12:3717-3732.

35 Tokhtaeva E, Sun H, Deiss-Yehiely N, Wen Y, Soni PN, Gabrielli NM, Marcus EA, Ridge KM, Sachs G, VazquezLevin M, Sznajder JI, Vagin O, Dada LA: The 0 -glycosylated ectodomain of FXYD5 impairs adhesion by disrupting cell-cell trans-dimerization of Na,K-ATPase $\beta$-subunits. J Cell Sci 2016;129:2394-2406.

36 Ino Y, Gotoh M, Sakamoto M, Tsukagoshi K, Hirohashi S: Dysadherin, a cancer-associated cell membrane glycoprotein, down-regulates E-cadherin and promotes metastasis. Proc Natl Acad Sci U S A 2002;99:365370.

37 Contreras RG, Shoshani L, Flores-Maldonado C, Lázaro A, Cereijido M: Relationship between $\mathrm{Na}(+), \mathrm{K}(+)-$ ATPase and cell attachment. J Cell Sci 1999;112:4223-4232.

38 Rincon-Heredia R, Flores-Benitez D, Flores-Maldonado C, Bonilla-Delgado J, García-Hernández V, VerdejoTorres O, Castillo AM, Larré I, Poot-Hernández AC, Franco M, Gariglio P, Reyes JL, Contreras RG: Ouabain induces endocytosis and degradation of tight junction proteins through ERK1/2-dependent pathways. Exp Cell Res 2014;320:108-118.

39 Larre I, Lazaro A, Contreras RG, Balda MS, Matter K, Flores-Maldonado C, Ponce A, Flores-Benitez D, Rincon-Heredia R, Padilla-Benavides T, Castillo A, Shoshani L, Cereijido M: Ouabain modulates epithelial cell tight junction. Proc Natl Acad Sci U S A 2010;107:11387-11392.

40 Ponce A, Larre I, Castillo A, Flores-Maldonado C, Verdejo-Torres O, Contreras RG, Verdejo-Torres 0, Contreras RG, Cereijido M: Ouabain Modulates the Distribution of Connexin 43 in Epithelial Cells. Cell Physiol Biochem 2016;39:1329-1338.

41 Ponce A, Larre I, Castillo A, García-Villegas R, Romero A, Flores-Maldonado C, Martinez-Rendón J, Contreras RG, Cereijido M: Ouabain increases gap junctional communication in epithelial cells. Cell Physiol Biochem 2014;34:2081-2090.

42 Larre I, Castillo A, Flores-Maldonado C, Contreras RG, Galvan I, Muñoz-Estrada J, Cereijido M: Ouabain modulates ciliogenesis in epithelial cells. Proc Natl Acad Sci U S A 2011;108:20591-20596.

43 Cereijido M, Contreras RG, Shoshani L, Larre I: The Na+-K+-ATPase as self-adhesion molecule and hormone receptor. Am J Physiol Cell Physiol 2012;302:C473-C481.

- 44 Farquhar MG, Palade GE: Junctional complexes in various epithelia. J Cell Biol 1963;17:375-412.

- 45 Meng W, Takeichi M: Adherens Junction: Molecular Architecture and Regulation. Cold Spring Harb Perspect Biol 2009;1:a002899.

46 Ozawa M, Baribault H, Kemler R: The cytoplasmic domain of the cell adhesion molecule uvomorulin associates with three independent proteins structurally related in different species. EMBO J 1989;8:17111717.

- 47 Nagafuchi A, Shirayoshi Y, Okazaki K, Yasuda K, Takeichi M: Transformation of cell adhesion properties by exogenously introduced E-cadherin cDNA. Nature 1987;329:341-343.

- 48 Clevers H: Wnt/ $\beta$-Catenin Signaling in Development and Disease. Cell 2006;127:469-480.

- 49 Contreras RG, Flores-Maldonado C, Lázaro A, Shoshani L, Flores-Benitez D, Larré I, Cereijido M: Ouabain binding to $\mathrm{Na}+, \mathrm{K}+-\mathrm{ATPase}$ relaxes cell attachment and sends a specific signal (NACos) to the nucleus.

J Membr Biol 2004;198:147-158. 


\section{Cellular Physiology Cell Physiol Biochem 2019;52:1381-1397 \begin{tabular}{ll|l|l} 
DOI: 10.33594/000000097 & O 2019 The Author(s). Published by \\
and Biochemistry
\end{tabular} and Biochemistry Published online: 11 May 2019 Cell Physiol Biochem Press GmbH\&Co. KG

50 Guerrero-Barrera AL, García-Cuéllar CM, Villalba JD, Segura-Nieto M, Gómez-Lojero C, Reyes ME, Hernández JM, García RM, de la Garza M: Actin-related proteins in Anabaena spp. and Escherichia coli. Microbiology 1996;142:1133-1140.

- 51 Cereijido M, Robbins ES, Dolan WJ, Rotunno CA, Sabatini DD: Polarized monolayers formed by epithelial cells on a permeable and translucent support. J Cell Biol 1978;77:853-880.

- 52 Soderberg K, Rossi B, Lazdunski M, Louvard D: Characterization of ouabain-resistant mutants of a canine kidney cell line, MDCK. J Biol Chem 1983;258:12300-12307.

- 53 Canessa CM, Horisberger JD, Louvard D, Rossier BC: Mutation of a cysteine in the first transmembrane segment of Na,K-ATPase alpha subunit confers ouabain resistance. EMBO J 1992;11:1681-1687.

54 Contreras RG, Avila G, Gutierrez C, Bolivar JJ, Gonzalez-Mariscal L, Darzon A, Beaty G, Rodriguez-Boulan E, Cereijido M: Repolarization of Na+-K+ pumps during establishment of epithelial monolayers. Am J Physiol Physiol 1989;257:C896-C905.

55 Schindelin J, Arganda-Carreras I, Frise E, Kaynig V, Longair M, Pietzsch T, Preibisch S, Rueden C, Saalfeld S, Schmid B, Tinevez JY, White DJ, Hartenstein V, Eliceiri K, Tomancak P, Cardona A: Fiji: an open-source platform for biological-image analysis. Nat Methods 2012;9:676-682.

56 Jouret F, Wu J, Hull M, Rajendran V, Mayr B, Schöfl C, Geibel J, Caplan MJ: Activation of the Ca2+-sensing receptor induces deposition of tight junction components to the epithelial cell plasma membrane. J Cell Sci 2013;126:5132-5142.

- 57 Martinez-Palomo A, Meza I, Beaty G, Cereijido M: Experimental modulation of occluding junctions in a cultured transporting epithelium. J Cell Biol 1980;87:736-745.

- 58 Volberg T, Geiger B, Kartenbeck J, Franke WW: Changes in membrane-microfilament interaction in intercellular adherens junctions upon removal of extracellular Ca2+ ions. J Cell Biol 1986;102:1832-1842.

59 Balda MS, Matter K: Tight junctions and the regulation of gene expression. Biochim Biophys Acta 2009;1788:761-767.

60 Islas S, Vega J, Ponce L, González-Mariscal L: Nuclear Localization of the Tight Junction Protein ZO-2 in Epithelial Cells. Exp Cell Res 2002;274:138-148.

61 Gottardi CJ, Arpin M, Fanning AS, Louvard D: The junction-associated protein, zonula occludens-1, localizes to the nucleus before the maturation and during the remodeling of cell-cell contacts. Proc Natl Acad Sci U S A 1996;93:10779-10784.

62 Balda MS, Garrett MD, Matter K: The ZO-1-associated Y-box factor ZONAB regulates epithelial cell proliferation and cell density. J Cell Biol 2003;160:423-432.

63 Cai H, Wu L, Qu W, Malhotra D, Xie Z, Shapiro JI, Liu J: Regulation of apical NHE3 trafficking by ouabaininduced activation of the basolateral $\mathrm{Na}+-\mathrm{K}+$-ATPase receptor complex. Am J Physiol Cell Physiol 2008;294:C555-C563.

64 García-Hernández V, Flores-Maldonado C, Rincon-Heredia R, Verdejo-Torres O, Bonilla-Delgado J, MenesesMorales I, Gariglio P, Contreras RG: EGF regulates claudin-2 and -4 expression through Src and STAT3 in MDCK cells. J Cell Physiol 2015;230:105-115.

65 Prassas I, Diamandis EP: Novel therapeutic applications of cardiac glycosides. Nat Rev Drug Discov 2008;7:926-935.

66 Flores-Maldonado C, Verdejo-Torres O, Campos-Blázquez J, Cabrera AR, García-Hernández V, RincónHeredia R, Contreras RG: Lysosomal Degradation of Junctional Proteins, in Sharma PD (ed): Lysosomes Associated Diseases and Methods to Study Their Function, ed 1. Rijeka, Croatia, InTech, 2017, pp 93-126.

67 Blanco G, Mercer RW: Isozymes of the Na-K-ATPase: heterogeneity in structure, diversity in function. Am J Physiol 1998;275:F633-650.

68 Ward SC, Hamilton BP, Hamlyn JM: Novel receptors for ouabain: studies in adrenocortical cells and membranes. Hypertens (Dallas, Tex 1979) 2002;39:536-542.

69 Balda M, Matter K: Epithelial cell adhesion and the regulation of gene expression. Trends Cell Biol 2003;13:310-318.

- 70 Ferrandi M, Molinari I, Barassi P, Minotti E, Bianchi G, Ferrari P: Organ hypertrophic signaling within caveolae membrane subdomains triggered by ouabain and antagonized by PST 2238. J Biol Chem 2004;279:33306-33314.

- 71 Contreras RG, Miller JH, Zamora M, González-Mariscal L, Cereijido M: Interaction of calcium with plasma membrane of epithelial (MDCK) cells during junction formation. Am J Physiol 1992;263:C313-C318. 


\section{Cellular Physiology Cell Physiol Biochem 2019;52:1381-1397}

\begin{tabular}{ll|l} 
and Biochemistry $10.33594 / 000000097$ & $\begin{array}{l}\text { D } 2019 \text { The Author(s). Published by } \\
\text { Cell Physiol Biochem Press GmbH\&Co. KG }\end{array}$ \\
\cline { 2 - 3 }
\end{tabular}

Castillo et al.: Ouabain Influences Adherens Junctions

- 72 Balda MS, González-Mariscal L, Contreras RG, Macias-Silva M, Torres-Marquez ME, García-Sáinz JA, Cereijido M: Assembly and sealing of tight junctions: possible participation of G-proteins, phospholipase C, protein kinase C and calmodulin. J Membr Biol 1991;122:193-202.

- 73 Contreras R, Shoshani L, Flores-Maldonado C, Lázaro A, Monroy A, Roldán M, Fiorentino R, Cereijido M: E-Cadherin and tight junctions between epithelial cells of different animal species. Pflugers Arch 2002;444:467-475.

74 Gumbiner B, Simons K: The role of uvomorulin in the formation of epithelial occluding junctions. Ciba Found Symp 1987;125:168-186.

75 Cadwell CM, Su W, Kowalczyk AP: Cadherin tales: Regulation of cadherin function by endocytic membrane trafficking. Traffic 2016;17:1262-1271. 